\title{
Forum
}

\section{Quintus in Britannia: visiting Roman Britain with the Cambridge Latin Course}

\author{
James Watson
}

\begin{abstract}
This article records its author's travels to sites in Britain that either provide settings for or are relevant to the stories of the Cambridge Latin Course. A version of this article was delivered as an oral presentation, entitled 'In the footsteps of Quintus Caecilius: visiting Roman Britain with the Cambridge Latin Course', at the American Classical League Centennial Institute in New York in June 2019. The article provides an overview of the sites, attempts to situate them in the geography and history of Roman Britain, and considers how such knowledge might be of benefit to teachers and learners.
\end{abstract}

Key words: Roman Britain, Cambridge Latin Course, archaeology, museums, teaching

The character of Quintus (Quintus Caecilius Iucundus), a fictionalised version of an individual known to have lived in Pompeii (from an electoral notice painted onto the wall of the House of Caecilius Iucundus: CIL, IV, 3433), is introduced as early as the third model sentence of Stage 1 of the Cambridge Latin Course, produced by the Cambridge School Classics Project (CSCP, 1998, p. 3). As is likely to have been the case for the 'real' Quintus (see Andreau, 1974 , p. 27 and pp. 36-37), the character is the son of Caecilius (Lucius Caecilius Iucundus); in Book I (or Unit 1 in the North American edition), he is presented as a teenager living in Pompeii. Following the AD 79 eruption of Mount Vesuvius, Quintus flees to Naples before travelling to Greece and then to Alexandria, as we read in the story 'Quintus de se' in Stage 16 (CSCP, 2000a, p. 67). During his time in Egypt Quintus stays with Barbillus, a business associate of his father, and it is the death of Barbillus in Stage 20 which prompts Quintus' next journey: as we read in the story 'astrologus victor II', Barbillus asks Quintus to deliver a letter to his son, Rufus, who is serving in the army in Britain (CSCP, 2000a, p. 139).

Quintus' time in Britain is described in Stages 14-16 of Book II and then throughout Book III (Stages 21-28), with his time in Egypt presented in Stages 17-20 of Book II as a flashback narrated by Quintus while he is in Britain. During the first half of 2019 I tried to follow 'in Quintus' footsteps' by going to the places the storyline of the Cambridge Latin Course imagines him visiting in Britain, and by attempting to trace the character's likely movements around the country. It might seem odd to seek to replicate the journeys of a fictionalised character, but by doing so - as I hope to show in this article - I learned more about Roman Britain in the first century $\mathrm{AD}$, and gained an improved understanding of the storyline of the Cambridge Latin Course. I hope that this information will be of

Author of correspondence: James Watson

Cite this article: Watson JM (2020). Quintus in Britannia: visiting Roman Britain with the Cambridge Latin Course. The Journal of Classics Teaching 21, 90-96. https://doi. org/10.1017/S2058631020000094 benefit to those who teach that course, as well as others with an interest in Roman Britain.

Before describing my travels and what I learned from them, I should present a disclaimer. The visits which I will discuss in this article were made between April and June 2019; anyone seeking to make a similar 'Quintus tour' of Britain should check current site opening times and ensure that they have planned their journeys carefully before setting off. As I learned on one particularly long day behind the wheel of my car, trying to follow Roman routes around modern Britain is not the quickest or most straightforward way of navigating the country; attempting to follow in the footsteps of a character from a textbook certainly requires some careful planning. To aid with such planning, I have included in this article the website addresses for the locations I visited. I should also note that - except where noted otherwise - my references to the Cambridge Latin Course are to the UK Fourth Edition, but I hope that by referring to Stages as well as pages and books this article will make sense to those who are familiar with a different edition of the course.

The Cambridge Latin Course textbooks are themselves silent about how Quintus travels from Alexandria to Britain. There is, however, a comment about that journey presented in the story 'itinera Quinti', one of the 'fabulae ancillantes' written by Stan Farrow and which support the North American Fourth Edition of the course (Farrow, 2007a, pp. 40-41). In that story, Quintus explains that, because it was dangerous to sail across the ocean, he chose to make the journey by going through Italy and Gaul via a crossing of the Alps. If we follow that plausible suggestion, we must imagine Quintus travelling by road to northern Gaul, and sailing from there to Britain itself.

The first place in Britain that we are told Quintus visits is Londinium: in the story 'in tablino', Rufilla reveals to her husband, Salvius, that she recently met Quintus, one of her relatives, while in the city. There are no stories which describe Quintus' time in London; while it would therefore be pure speculation to suggest what

(c) The Author(s) 2020. Published by Cambridge University Press in association with The Classical Association. This is an Open Access article, distributed under the terms of the Creative Commons Attribution-NonCommercial-NoDerivatives licence (http://creativecommons.org/licenses/by-nc-nd/4.0/), which permits non-commercial re-use, distribution, and reproduction in any medium, provided the original work is unaltered and is properly cited. The written permission of Cambridge University Press must be obtained for commercial re-use or in order to create a derivative work. 
he may have seen there, a few general observations, which help to set the scene for Quintus' time in Britain as a whole, are worth making. Quintus' arrival in Britain is dated to AD 82 (see, for example, CSCP, 1983, p. 50), at which point it seems likely that he is aged 19-20 (in Stage 9, presumably to be dated to relatively shortly before the eruption of $\mathrm{AD} 79$, he celebrated what is likely to have been his sixteenth birthday, meaning that we can suggest that Quintus was born c. AD 62-63). It is worth reminding ourselves therefore that Quintus reaches Britain as a young man, and only 21 or 22 years after the revolt led by Boudica in AD 60 or 61 . The Londinium that Quintus visited would have been a city that had only stood for around 20 years, as he would have seen the city that was rebuilt after the destruction wreaked by the British Iceni tribe and their allies. Britannia had, furthermore, only become a Roman province 39 years before Quintus' arrival, following Claudius' invasion of AD 43. When considering Quintus' time in Britain, therefore, we should remember that he views it with the eyes of a young man, and that he is visiting somewhere that had been part of the Roman Empire for less than half a century and which had seen a major rebellion against Roman rule only around two decades earlier. It may be of interest to know that the Stage 16 Attainment test for the North American Fifth Edition of the Cambridge Latin Course is based on a story entitled 'Bregans de se', in which Bregans, one of Salvius' slaves, reveals that he belonged to the Iceni tribe, that his father and brothers had been killed by the Romans during the rebellion, and that he had been sold into slavery in its aftermath - a story which therefore reminds us that the Britons of Quintus' day belonged to tribes, and that characters he encounters in Britain may have experienced the tumultuous years that preceded his arrival and may feel considerable hostility towards the Romans.

If Londinium is the first place that we are told Quintus visits, the first place that we see him in Britain - and indeed the first setting introduced in Book II - is Salvius' 'villa magnifica' (CSCP, 2000a, p. 2). That setting is based on a real archaeological site: 'We have imagined the home of Salvius in Britain as being Angmering near Worthing in [West] Sussex, where excavations, now unfortunately covered up, have revealed a villa, unusually elaborate for the first century' (CSCP, 1983, p. 10). The location of the villa is marked on Ordnance Survey maps and is in the fields to the west of Angmering; the site can be viewed from a footpath across the fields between Angmering and the village of Poling. There are no visible traces of the villa, but the fact that its location is still used for agricultural purposes - crops and livestock were both in evidence on my visit in May 2019 - helps to reinforce the rural nature of Salvius' home (www.angmeringvillage.co.uk/history/villa.htm).

Information about the villa and finds recovered from the site are presented at the nearby Littlehampton Museum (www.littlehamptonmuseum.co.uk). On display are fragments of painted wall plaster, mosaic flooring, marble tiles and window glass, which help to give a sense of what the building must once have been like. The lives of the villa's inhabitants are illustrated by other finds, such as blue glass beads, a loom weight, spindle whorls, clay slingshot, bone knife handle mounts and the fragments of a possible bone flute. Also on display are oyster shells, which show that Rufilla's preparation of a meal of oysters for Quintus, as recounted in the story 'Quintus advenit' in Stage 14 (CSCP, 2000a, p. 32), replicates an activity that really did occur at the villa. The display also includes a chalk gaming counter on to which the word 'Cretici' seems to have been scratched; from this, it is suggested that the counter may have belonged to a Romanised Briton named Creticus - perhaps a reallife equivalent of some of the British slaves depicted in Stages 13 and 14. As 'the ground plan of the domestic range at Angmering has yet to be recorded, though an elaborate and structurally independent bathhouse has been extensively examined' (Russell, 2014, p. 142), we must await any future archaeological work on the site for a better picture of the real 'Salvius' villa' to emerge.

Those hoping to see what Salvius' villa might once have looked like can form an impression from a mural painting in Littlehampton Museum of a Romano-British estate, although I also found a visit to the 'Roman Villa' at Butser Ancient Farm (www. butserancientfarm.co.uk) - some 22 miles, as the crow flies, from the villa site - very useful for giving a sense of what might once have stood at Angmering. Butser's Roman Villa is actually a reconstruction of the somewhat later villa excavated at Sparsholt, Hampshire, but it nonetheless helps to give an impression of what a villa in the Romano-British countryside might have been like. Additionally, one of the rooms of Butser's Roman Villa could hardly have been decorated better to help visualise the storyline of Stage 14, for it contains a cupboard, chair and candelabrum three items which Rufilla orders to be moved into Quintus' bedroom, much to Salvius' annoyance. Also nearby (less than 8 miles as the crow flies from the site of the villa at Angmering) is Bignor Roman Villa, whose remains, which admittedly are later than the first century $\mathrm{AD}$, also give an impression of what Romano-British villas were like and include some very impressive mosaics (www.bignorromanvilla.co.uk).

As Quintus travelled in Britain, he would also have seen houses rather different from Salvius' villa. The Iron Age Enclosure at Butser Ancient Farm contains several reconstructions of roundhouses, of the type portrayed in Books II and III as the homes of Britons, which help to illustrate the contrast between Roman villas and Iron Age dwellings. The building that appears on the title page for Stage 13, described as 'a reconstruction of [an] early Romano-British farmstead' (CSCP, 2000b, p. 7) is the 'Roman House' which formerly stood in Upton Country Park in Dorset, but unfortunately it was destroyed by fire in 2014 and so cannot now be visited.

The most impressive residence that Quintus visits in Britain is the palace of King Cogidubnus, a setting based on the remains of a palace site located in the modern village of Fishbourne (http:// sussexpast.co.uk/properties-to-discover/fishbourne-romanpalace). The palace is first mentioned in the Stage 14 story 'tripodes argentei' when Quintus learns that Salvius has been invited there by the king (CSCP, 2000a, p. 33), and it then provides the setting for Stages 15-16, the start of 21, and 28 (as well as, technically, for Stages 17-20, as Quintus is at the palace when he tells Cogidubnus about his time in Egypt). Quintus' first journey from Salvius' villa to Cogidubnus' palace is described in Stage 15 in the story 'ad aulam' (CSCP, 2000a, pp. 46-47), and after that he becomes a frequent visitor to the palace, as we are told at the start of Stage 21 in the story 'fons sacer' (CSCP, 2001, p. 5). To travel from Salvius' villa to Cogidubnus' palace, Quintus would presumably have made use of the Roman roads numbered 153 and 421 in Margary's study of the Roman roads in Britain, which proved an indispensable aid in my efforts to re-create Quintus' travels (Margary, 1955-1957); their route is roughly traced by the modern A27 road. The journey between the two sites looks to have been just over 13 miles, which for someone travelling on foot at $3 \mathrm{mph}$ would have taken around $41 / 2$ hours. Given the frequency of Quintus' visits to the palace while staying at Salvius' villa, perhaps we should infer that he usually - as he did in 'ad aulam' - travelled on horseback: at a canter (12-15 $\mathrm{mph}$ ), a horse could have carried Quintus that distance in about one hour.

On arrival, Quintus would have found a palace that was newly-built. 'It was some time between $\mathrm{AD} 75$ and 80 that the 
construction of the great palace began' (Cunliffe, 2010, p. 49), and so we have to imagine the palace as having stood in the form that Quintus saw it for no more than seven years before his arrival. Approximately half of the palace now lies beneath modern houses and the A259 road, but the excavated north range, preserved under a cover building, can be visited, along with traces of the west and east ranges and the gardens, which are in the open air. Adjacent to the excavated north range is a small museum with finds from the site and information about it.

One of the information boards in the museum helps to suggest the impression that the palace - a building unlike any he would have encountered in Pompeii - would have made on Quintus and other visitors. It suggests that the palace - the footprint of which is essentially a square with sides around 150 metres in length dwarfed other residences in Britain, and should instead be compared with the size of the imperial palaces in Rome; the plan of the site at Fishbourne is displayed alongside plans of Nero's Golden House and Domitian's Palace in Rome, the latter of which - itself a Cambridge Latin Course setting from Stage 33 onwards - has at its heart a footprint of very similar shape and size. Two Romano-British villas are also shown, to scale, on the same sign, which comments that the 'comparison with contemporary Romano-British country houses serves to emphasise the vast scale of the Fishbourne Palace and the difference in status between the normal landowner and the owner of this building. An excellent introductory video shown at the site - currently also available on YouTube - includes comments by the former director of the site, David Rudkin, which make a similar point: 'Just imagine what it might have felt like to be one of those farmers walking along this road on your first visit to the palace... You've never seen anything like it... Finally you approach the audience chamber at the centre of the west wing, where the owner awaits you. By this time, you're totally intimidated, and your knees are trembling' (http://youtu.be/7S8OoHmlRl4). This palace was unlike anything else in Britain - and, indeed, anything else that Quintus would see anywhere until he goes to Rome itself at the end of the course storyline.

In the Cambridge Latin Course the owner of the palace (at least prior to Stage 28) is Cogidubnus, a client king of the Romans, at the head of the Regnenses tribe. The historical figure on which the character is based is a plausible candidate to have been the real owner of the palace at Fishbourne (see Cunliffe 2010, pp. 108-109). The real king's name has been variously interpreted; at Fishbourne the decision seems to have been taken to refer to him now as Togidubnus, as newer signs in the museum give this form rather than Cogidubnus. The museum contains a marble statue head of a young man (although on my visit it was a replica that was on display) which is interpreted as possibly being a member of the king's family. Its label comments that it 'could be the only hint of what Cogidubnus [sic] may have looked like'.

The palace underwent many changes in its history, but it is relatively easy for a visitor to the site to see traces of the first-century palace that Quintus would have seen. First-century mosaics are visible, sometimes in situ; indeed, some of them can only be glimpsed through gaps in the later mosaics subsequently laid on top of them. The very floor which the course invites us to imagine as the setting for the events of the Stage 16 story 'rex spectaculum dat', during which Quintus saves Cogidubnus from the bear (CSCP, 2000a, pp. 63-64) - or, more prosaically, the first-century mosaic from the palace's dining room - can be seen, though it has been moved from its original location. Reconstructions of a dinner party taking place in the dining room with a representation of this original flooring (known as the Fortress mosaic as its border depicts fortifications) can be seen in the site introductory video. The dining room itself now contains the famous mosaic of Cupid on a Dolphin, which was subsequently laid on top of the first-century floor; a photograph of this later mosaic appears as part of the paralinguistic material for Stage 16 (CSCP, 2000a, p. 71).

The first two model sentences in Stage 16 refer to aspects of Cogidubnus' palace that can also be seen by visitors to the site today (CSCP, 2000a, p. 60). In the first, Cogidubnus shows Quintus the palace's wall paintings, traces of which remain in situ in the excavated north range; fragments of wall paintings can also be seen in the museum, including one showing a coastal scene, stated to be similar to a wall painting from Stabiae. In the second model sentence, Cogidubnus takes Quintus into the garden; the modern visitor can form an impression of the ancient gardens from replanted hedges and trees, as well as the so-called plant display garden.

One presumes that, on his journeys from Salvius' villa to Cogidubnus' palace, Quintus passed through the town of Noviomagus (modern Chichester). An object that we can plausibly suggest that Quintus might have seen in Noviomagus is now to be seen built into the wall of Chichester's Council House: an inscription recording the dedication of a Temple of Neptune and Minerva, which includes the name of Cogidubnus (or Togidubnus). This is the inscription which appears on the title page of Stage 15 and is subsequently discussed in that stage's paralinguistic material (CSCP, 2000a, p. 43 and p. 55). The modern visitor to Chichester can also see traces of the city's Roman walls and visit The Novium Museum (www.thenovium.org), which contains information about and finds from the local area as well as the excavations of a bath house.

At the start of Book III we learn that Quintus stayed with Salvius throughout the winter, often visiting Cogidubnus, and that, in the spring of $\mathrm{AD} 83$, Quintus accompanied the king, who had fallen ill and was seeking a cure, to Aquae Sulis (modern Bath). The textbook does not give any details of the journey from the palace to Aquae Sulis, but the Stage 21 Attainment test for the North American Fifth Edition of the course is based on a story, 'Cogidubnus iter facit', which reveals that Cogidubnus and four slaves travelled to Aquae Sulis for several days through a very thick forest. If Cogidubnus and his associates travelled by road, they are surely likely to have left Noviomagus on Margary's road 421, before turning to the north to follow road 420 to Winchester, then road 43 to Mildenhall (near Marlborough), before turning west on road 53 to reach Aquae Sulis, passing the Neolithic mound of Silbury Hill en route - a journey of 90 miles. If this journey - which is not one that I tried to re-create - was made on foot at $3 \mathrm{mph}$, it could have been completed in 5 days (assuming 6 hours of travelling per day). Part of the 'Cogidubnus iter facit' story mentions that there was a waggon on hand, so it is possible that the journey was not undertaken solely on foot, and could therefore have been completed more quickly. In any case, it is instructive to recognise that whilst a journey between Chichester and Bath could today be completed in $21 / 2$ hours (by a different route), a first-century journey between Noviomagus and Aquae Sulis was a significantly longer one. We must imagine Quintus going on this (or a similar) journey to Aquae Sulis, and it is intriguing to think of him contemplating Britain's pre-Roman history as he travelled past Silbury Hill; the idea of him making a detour to nearby Avebury is entirely speculative, but plausible given his desire to visit the Pyramids during his time in Egypt, as described in the story 'ad pyramidas' in the second attainment test for Book II (CSCP, 2000b, pp. 83-84). We might wonder what Quintus might have made of the traces of a very ancient, very un-Roman past, in Egypt and Britain alike. Quintus probably 
would not, however, have seen Stonehenge due to the routes of the roads he is likely to have followed - much to my disappointment when first considering his probable route, having seen that the site lies just a couple of miles from a straight line linking Chichester and Bath.

A modern visitor to the remains of Aquae Sulis (www.romanbaths.co.uk) will soon see the truth of the comment that opens the Stage 21 story 'Lucius Marcius Memor': 'the town of Aquae Sulis was small, the baths very big' (CSCP, 2001, p. 6). When Quintus sees the baths for the first time in Stage 23's 'in thermis II', he is astonished, saying 'these baths are bigger than the Pompeiian baths!' (CSCP, 2001, p. 39). As was the case with Cogidubnus' palace, the baths of Aquae Sulis were on a grand scale and were unlike anything Quintus had seen before. They too had only recently been built at the time of Quintus' visit: one of the information signs in the Roman Baths Museum comments that 'the earliest inscription from the baths... is from a small monument and dates to $76 \mathrm{AD}$, so the baths must have been built by then'. If that is correct, the complex at Aquae Sulis had been built for only around seven years by the time that Quintus first saw it. The model sentences of Stage 21, as well as Cogidubnus' comments in its first story, 'fons sacer', also give an impression of the baths complex as a new or even an ongoing construction project (CSCP, 2001, pp. 2-5).

Although much of what remains of Aquae Sulis lies beneath modern buildings, the modern visitor can see a considerable amount of the ancient bath and temple complex and form an impression of what Quintus would have seen. One can view the altar and forecourt that lay in front of the Temple of Sulis Minerva, some of the steps which once led to that temple, and a gilt bronze head of Sulis Minerva herself, probably from the temple's cult statue. The decoration of the temple's pediment, with its 'Gorgon head' design, is on display in the museum and is 'restored' to its ancient condition by a sequence of projections, one of which fills in the gaps in the pediment, another of which adds the ancient colour scheme. There are also videos that present computer-generated reconstructions of the site which help the visitor to visualise the ancient appearance of the buildings; one of these can currently also be viewed on the museum website (www.romanbaths.co.uk/videos/ education/computer-reconstruction-temple-courtyard).

In those videos appears a character who is at once familiar and unfamiliar to readers of the Cambridge Latin Course: the haruspex Lucius Marcius Memor. The interpretation of this character in the videos shows him wearing his distinctive headgear and attentively dealing with visitors to the complex - he is thus rather different from the 'homo...ignavus' of Book III, introduced in the story named after him in Stage 21 (CSCP, 2001, p. 6). The so-called 'Haruspex Stone', carrying an inscription which shows that it was dedicated to Sulis by the real-life Lucius Marcius Memor, can be seen near to the goddess's altar. A sign close to the modern visitors' entrance reveals that Memor is one of the characters that can be met on the children's audio tour of the site, although this was not an option that I took.

A visit to the Roman Baths Museum allows one to view many other locations and finds related to the storyline of Book III. Most obviously, one can tour the baths themselves, including the largest bath, into which Cogidubnus was lowered as he sought his cure in 'in thermis II' (CSCP, 2001, p. 39). Nearby is the sacred spring, its shape transformed after the Roman era, but with the hot water still bubbling up to the surface. The museum contains a vast number of finds from the complex, including a selection of defixiones (curse tablets), amongst them the one which refers to Vilbia and was the inspiration for the Stage 22 storyline. What struck me most about the curse tablets on seeing them was how small they are - the Vilbia tablet, for example, is, roughly, a square with sides slightly less than $7 \mathrm{~cm}$ long. Anyone seeking illustrations for the story 'Vilbia' in Stage 22 (CSCP, 2001, p. 24) will be pleased to find many brooches on display in the museum as well.

Quintus' time in Aquae Sulis ended when he and Dumnorix, chief of the Regnenses, set out to report the nefarious actions of Salvius and the arrest of Cogidubnus to the provincial governor, Gnaeus Julius Agricola - whom Quintus will eventually meet at Deva (modern Chester). Their departure from Aquae Sulis is related in 'Quintus consilium capit' in Stage 24 (CSCP, 2001, p. 58). On this occasion, the textbook does provide a clue as to the route taken by Quintus and Dumnorix: a photograph given the caption 'Aerial view of the Shropshire section of the Roman road followed by Quintus and Dumnorix to Chester' (CSCP, 2001, p. 62). The Teacher's Guide reveals that, specifically, the photograph shows 'Watling Street West, entering the Church Stretton gap, looking south' (CSCP, 2002, p. 48); this is not the more famous Watling Street, which ran from Richborough, Kent, via London (Londinium) and St Albans (Verulamium) to Wroxeter (Viroconium), but a different road which 'passes through Wroxeter...connecting the main legionary fortresses at Chester and Caerleon.... This road should not be considered as a part of the main Watling Street, and it will, therefore, be convenient to add the suffix (West) as a distinction' (Margary 1957, p. 30). Anyone seeking to re-create Quintus' journey from Aquae Sulis to Deva needs, therefore, to travel along the section of Watling Street (West) shown in the photograph. Given the desire of Quintus and Dumnorix to reach Chester without detection by Salvius and any soldiers loyal to him, I did consider the possibility that they would in fact have sought to make their journey without using the road network, but this photograph suggests that the textbook does envisage the characters travelling by road, which we can speculate they may have chosen to do anyway in the interests of speed.

On a very wet day in June 2019, I set off from Bath to see if I could follow a plausible Roman route to Chester, to include the photographed section of Watling Street (West). The obvious choice for the first part of the journey was to follow the Foss Way (Margary 5c) from Bath to Cirencester (ancient Corinium). This is no longer a main road, but with its unmistakably Roman straightness it can be followed for much of the way to Cirencester, although for some of the journey I needed to make detours from it. There is much of Roman interest to explore in Cirencester, but all I had time for on my journey was a brief visit to the remains of its amphitheatre (www.english-heritage.org.uk/visit/places/cirencester-amphitheatre). I then headed towards Gloucester (ancient Glevum) on the route of Ermin Street (Margary 41c, to be distinguished from the Ermine Street which linked London to York); for the first part of the journey from Cirencester the A417 follows the line of the Roman road, but at the steep Birdlip Hill one must switch to more minor modern roads to follow the Roman route into Gloucester. Beyond Gloucester, I found it harder to be sure that I was following Roman roads until, just north of Hereford, I joined the A4110 Watling Street (West) (Margary 6c) - which I followed to Leintwardine. Watling Street (West) continued beyond Leintwardine (Margary 6b), and I was able to follow it to Church Stretton; a series of different modern road numbers have been assigned to this route, although it is the A 49 by the time it reaches Church Stretton. Soon after that town one has to leave the A49 to follow the line of the Roman road on minor modern roads towards Wroxeter (ancient Viroconium); I followed the Roman route successfully for part of this leg of my journey, but I had to deviate from it as I drew near to Wroxeter (near Shrewsbury). The extensive and interesting remains 
of Wroxeter Roman City (www.english-heritage.org.uk/visit/ places/wroxeter-roman-city) - once the fourth largest town in Britain - provided a welcome break after many hours of driving, and are well worth exploring, along with their museum. The site is dominated by the remains of a bath complex, but some remains of the forum and a reconstruction of a third-century town house can be seen across a modern road which lies atop Watling Street (West). Quintus, however, would have seen nothing of this city, as in AD 83 there was a military fort rather than a civilian settlement at the site. From Wroxeter I continued to follow Watling Street (West) (Margary $6 \mathrm{a}$ ), as far as I was able, until I finally reached Chester.

I have described my journey from Bath to Chester - which took approximately $61 / 2$ hours of driving, plus stops - in detail to help emphasise its length. To say 'Quintus travelled from Bath to Chester' takes virtually no time, but to undertake that journey - even today - is a slow process. The route I had planned to take - to my mind the most plausible one that follows Roman roads - is approximately 150 miles in length (my actual route was somewhat longer, as my journey was lengthened by not always being able to follow my intended route, as well as by detours and wrong turns). Quintus and Dumnorix seem to have expected their journey to take 5 days - in the Stage 24 story 'Quintus consilium capit' they take with them food to last for that amount of time (CSCP, 2001, p. 58) - so they would need to have covered around 30 miles a day to complete the journey before their food ran out. As they set out on horseback, such a rate of progress would have been plausible: ORBIS, the Stanford Geospatial Network Model of the Roman World (http://orbis. stanford.edu), assumes that a horse could travel $56 \mathrm{~km}$ (i.e. 34.7 miles) in a day, and so the characters' judgement of how much food to take with them looks sensible. On foot, though, this would have been a journey of around 8 days, assuming a walking pace of $3 \mathrm{mph}$ and a daily travelling time of 6 hours.

Although both Quintus and Dumnorix set out from Aquae Sulis, only Quintus survives the journey. As we read in Stage 24's 'Salvius consilium cognoscit', the pair are pursued for three days by Salvius' soldiers, and then attacked in a wood; Dumnorix is killed, but Quintus escapes (CSCP, 2001, p. 62). We must, presumably, imagine that this attack occurred roughly three-fifths of the way through the journey, which would put it somewhere in the vicinity of Church Stretton - making the photograph of that stretch of the road, which accompanies the story of the attack in the textbook, especially well chosen. Thereafter Quintus had to complete a journey of perhaps 60 miles - injured, and now on foot, and presumably at a relatively slow pace - to reach his destination of Chester.

Quintus himself expresses, before setting off from Aquae Sulis, a sense of how far he needs to travel to find Agricola: in the story 'Quintus consilium capit' in Stage 24, when Quintus tells Dumnorix that they must hurry to 'the furthest parts of Britain' to reach him (CSCP, 2001, p. 58). That comment also suggests Quintus' limited awareness of just how much of Britain actually lies to the north of Chester, but it is hardly surprising that this was his opinion, as the north of the island had yet to be well explored by the Romans; the story thereby suggests something of the first-century Roman understanding of British geography. It is possible that Quintus and Dumnorix actually thought they needed to seek Agricola further to the north, in Scotland, where the governor was waging war: the storyline of Stage 37 'follows Agricola's victory at Mons Graupius in AD 84' (CSCP, 2005, p. 5), where we read of his successes against the Caledonii. Given the amount of food taken by Quintus and Dumnorix when they set out from Aquae Sulis, and the route they are shown to have taken, however, it seems that Deva (Chester) was their intended destination in the storyline. Even though they cannot have known that Agricola would visit Deva at just the right time for Quintus to see him, we could speculate that they intended to travel there before heading still further north if necessary which it proved not to be.

I was surprised to discover, by completing my journey from Bath to Chester, the variety of fates that have befallen Roman roads. At times - most notably on the A417 in the direction of Gloucester from Cirencester - modern trunk roads lie on the route of their Roman predecessors. At other times, though - including the Foss Way between Bath and Cirencester, and Watling Street (West) between Church Stretton and Wroxeter - the roads are fairly narrow lanes which nonetheless often betray their Roman origins due to their straightness and occasionally the names that they still bear over certain stretches. At times it simply was not possible to follow the Roman routes, as roads that follow them seem no longer to exist. When initially considering my trip, I had checked on Google Maps to see if it looked feasible to drive from Bath to Chester in a day, and was reassured to see that a journey between the two locations could be completed in under 4 hours. That route, though, owed very little to Roman roads, as it involved a longer route dominated by the M5 motorway. My attempt to follow a Roman route shortened the distance I had to cover but significantly increased my journey time - and also revealed, at least for this route, that even where towns are in the same location, those of modern Britain are connected differently from those of Roman Britain.

150 miles of Roman road may have separated Aquae Sulis from Deva, but it may have seemed to Quintus like he was travelling to a different world. Although there were soldiers in Aquae Sulis, at Deva what he would have found was a major legionary fort, 'built in about $75 \mathrm{AD}$ by the Roman II Legion on a rocky sandstone outcrop at the mouth of the sacred Celtic river' (Emery, 2017, p. 5). It had therefore been in place for around eight years by the time Quintus reached it in AD 83, and it marked the fact that Quintus was now close to the frontier of the Roman Empire, having left the relatively peaceful south of Britain behind him. The remains of the Roman fort lie beneath the centre of the modern city of Chester; the characteristic 'playing card' shape of a Roman fort is still discernible in aerial photographs, as three sides of the fort are still marked by the city walls that in some places contain Roman layers, whilst its via principalis lies under the modern Watergate and Eastgate Streets, with the via praetoria under Bridge Street.

In Stages 25 and 27, the stories set in the fort (or camp, as the site is routinely called a 'castra' in the textbook) focus on Modestus and Strythio, rather than on Quintus. Much of the action in Stage 25 is centred on the prison; there is no evidence for the location of the prison at Chester, although if it actually stood where it is marked on the plan in the paralinguistic material for Stage 27 (CSCP, 2001, p. 115), it would be found in the vicinity of Chester Cathedral. In Stage 27, the majority of the action shifts to one of the granaries. These structures do seem to have stood in an area of the fort that is bounded by the modern city's Watergate and Commonhall Streets, where I found on my visit in June 2019 that there was, amongst other buildings, a café: food is now easier to come by in that location than it was for Modestus in the stories.

A clearer impression of an ancient granary is formed from a visit to Lunt Roman Fort, on the outskirts of Coventry - a Roman fort that was partially rebuilt in the 1970s to give an impression of its ancient appearance (www.luntromanfort.org). The reconstructed granary there appears in a photograph in the textbook (CSCP, 2001, p. 107), and at the site one can also see, reconstructed in wood, part of the eastern camp walls, complete with a gate which resembles that drawn to accompany the Stage 25 model sentences (CSCP, 
2001, p. 72; there is also a picture of the gate at Lunt on p. 119). A museum housed in the reconstructed granary presents information about and finds relating to the fort and the Roman army, and the site also contains a reconstructed gyrus (a ring for cavalry training).

Back in Chester, the location that most closely relates to Quintus' story is the principia, or legionary headquarters. It is into this building that Quintus bursts, exhausted, at the end of his journey from Aquae Sulis, as we read in Stage 26 in the story 'in principiis', and was presumably where Quintus and Agricola then spoke once the former's identity had been confirmed by Rufus - Barbillus' son, conveniently present as a military tribune - in the following story, 'tribunus' (CSCP, 2001, p. 92 and p. 95). The principia now lies under modern buildings, most notably St Peter's Church, whose tower stands near where the arched entrance to the complex once stood. The excavated strong room of the principia (which reveals the location of the basilica) can be seen below ground level through glass windows from an alley that links Northgate Street with Hamilton Place. Not far away, on Northgate Street, is displayed (alongside other pieces of masonry, mostly Roman) a column base from the principia. A model that shows what the whole principia complex would have looked like is to be found in the nearby Grosvenor Museum, which also contains a vast array of interesting items, some of which appear as illustrations in the second half of Book III (http://grosvenormuseum.westcheshiremuseums.co.uk). Of particular relevance are antefixes of the Twentieth Legion, similar to the one used as the title page for Stage 26 (CSCP, 2001, p. 89), a lead water pipe dating to AD 79 and carrying the name of Agricola (CSCP, 2001, p. 91), and the model of Deva used as the title page for Stage 27 (CSCP, 2001, p. 105), but the museum's Roman collections are extensive and of great interest beyond those items familiar from the Cambridge Latin Course.

A visitor to Chester can see many other sites of Roman interest. The Dewa Roman Experience contains life-size replicas of many features of the ancient fort and settlement, allowing an impression to be formed of what it would have been like to visit during antiquity (www.dewaromanexperience.co.uk). Much information and many finds are also presented there, and there are excavations within the 'experience', which include parts of what was probably the valetudinarium (hospital). A circuit can be made of the City Walls which (as noted above) follow the line of the walls of the Roman fort on three sides. Of particular interest along the way are the 'Roman Gardens', where Roman building fragments are displayed (not in their original location), and a particularly well-preserved stretch of Roman wall near the Northgate. That location also helps one to understand the way in which the fort was built on high ground, which is not easily appreciated amongst the buildings of the city centre: there a canal has been dug deep into the rock on which the fort was built, revealing how much above river level the site of the fort was. The remains of a Roman amphitheatre that stood just outside the fort can also be seen (www.english-heritage. org.uk/visit/places/chester-roman-amphitheatre); beyond it lay the vicus, or civilian settlement, which the Cambridge Latin Course imagines as the place of residence of Nigrina, Modestus' preferred saltatrix (CSCP, 2001, p. 107). Also outside the fort, and now in the grounds of Chester Racecourse, can be seen the remains sometimes interpreted as part of the Roman quayside (CSCP, 2001, p. 96).

As far as the textbooks are concerned, Quintus' journey in Britain ended at Deva; indeed, after his appearance in Stage 27 he does not feature in the stories until the denouement of the whole course, set in Rome, in Stage 40. One of the 'fabulae ancillantes' - entitled 'Quintus exire parat' - plausibly imagines Quintus wanting to leave Deva to return to Italy immediately, and sees Agricola promise him an armed escort (implied but not stated to be Modestus and Strythio) to the coast (Farrow, 2007b, pp. 18-19). Agricola himself features again in the final stage to refer to matters in Britain, Stage 37; there we read of his victory at Mons Graupius, and of Domitian's deliberations about the governor's future.

When I first conceived of the idea of trying to visit all the places in Britain that provide settings for parts of the Cambridge Latin Course, I naturally expected to see some interesting sites and to learn from them, but the process of planning and completing my 'Quintus tour' ended up enhancing my knowledge of Roman Britain and the Cambridge Latin Course in ways that I had not anticipated. I certainly emerged from the process with a much better sense of the scale of Roman Britain, of how its different settlements were connected, and of how long journeys around the province might have taken. This in turn made me realise that I should have spent longer making such information clearer to my students when teaching, rather than just moving from one story to another without discussing the geography of Roman Britain and what a change of setting might have meant for the characters, and without even remarking on how long it might have taken them to make the journeys imagined by the stories. I also became much more aware of the fact that the Britain visited by Quintus was still an emerging province; although this is made clear by the stories (and paralinguistic material), actually recognising that they are set so relatively soon after the Roman conquest of Britain, and even sooner after Boudica's rebellion, was a step I had never quite taken before.

That recognition that Britain was a new and, in many ways, unfamiliar (to Quintus and other Romans) part of the Roman Empire has also suggested to me an approach that I would take in my teaching if ever I have the opportunity to teach Books II and III again. A difficulty that is sometimes found with the transition from Book I to Book II is that the dramatic climax of the former in Stage 12 - with the destruction of Pompeii in the AD 79 eruption of Mount Vesuvius - is followed in Stages 13 and 14 by a set of stories describing somewhat mundane life on a Romano-British rural villa estate (and slightly more exciting events that occurred in a mine, stated to be in Kent, but whose precise location is unspecified and thus did not form part of my tour). I tended to begin my teaching of Stage 13 by exploring how the dwelling and people depicted on its title page (CSCP, 2000a, p. 1) differed from what we had learned about Caecilius and his house during Book I, but thereafter consideration of how Roman Britain differed from Roman Italy would disappear from my lessons. I now wonder whether trying to encourage students to experience all the stages set in Roman Britain through the eyes of Quintus - who, as I have suggested, would regularly have been encountering unfamiliar and highly unusual settings, as well as characters with a wide range of personal histories and motivations - might in fact help them to share the excitement that the character must have felt in exploring somewhere that was so different from what he had experienced before, and might also therefore help to sustain interest and momentum through Books II and III.

Above all, making my 'Quintus tour' helped me to appreciate again not only how carefully the Cambridge Latin Course was written but also how the experience of reading the stories of the course can be enhanced through an improved knowledge of their settings. Although not everyone reading this will have the time, opportunity or inclination to physically follow in Quintus' footsteps - and now also my own - in tracing his route around Britain, I hope that describing how I did so and what I found will at least enable others to be able to make the journey in their mind (or perhaps on the internet), and thereby to gain, as I did, an improved understanding of both the Cambridge Latin Course and Roman Britain. 


\section{References}

Andreau J (1974) Les affaires de Monsieur Jucundus. Rome: École française de Rome. CSCP (1983) Cambridge Latin Course Units IIA and IIB Teacher's Handbook (2 $2^{\text {nd }}$ ed.). Cambridge: Cambridge University Press.

CSCP (1998) Cambridge Latin Course Book I ( th $^{\text {th }}$ ed.). Cambridge: Cambridge University Press.

CSCP (2000a) Cambridge Latin Course Book II ( $4^{\text {th }}$ ed.). Cambridge: Cambridge University Press.

CSCP (2000b) Cambridge Latin Course Book II Teacher's Guide (4 ${ }^{\text {th }}$ ed.). Cambridge: Cambridge University Press.

CSCP (2001) Cambridge Latin Course Book III ( $4^{\text {th }}$ ed.). Cambridge: Cambridge University Press.

CSCP (2002) Cambridge Latin Course Book III Teacher's Guide (4 ${ }^{\text {th }}$ ed.). Cambridge: Cambridge University Press.

CSCP (2005) Cambridge Latin Course Book V Teacher's Guide (4 ${ }^{\text {th }}$ ed.). Cambridge: Cambridge University Press.

Cunliffe B (2010) Fishbourne Roman Palace. Cheltenham: The History Press.

Emery G (2017) Roman Chester - Deva. Chester: Gordon Emery.

Farrow S (2007a) Cambridge Latin Course Units 1 and 2 fabulae ancillantes. Cambridge: Cambridge University Press.

Farrow S (2007b) Cambridge Latin Course Units 3 and 4 fabulae ancillantes. Cambridge: Cambridge University Press.

Margary ID (1955-1957) Roman roads in Britain. [Volume I. South of the Foss Way - Bristol Channel (1955); Volume II. North of the Foss Way - Bristol Channel (including Wales and Scotland (1957).] London: Phoenix House.

Russell, M (2014) Roman Sussex. Cheltenham: The History Press.

\section{Further Reading}

Bird S \& Cunliffe B (2006) The Essential Roman Baths. London: Scala Arts \& Heritage Publishers Ltd.

Cunliffe B (2009) Roman Bath Discovered. Cheltenham: The History Press.

Cunliffe B (1977). Fishbourne Roman Palace: A Guide to the Site. Lewes: Sussex Archaeological Society.
Cunliffe B (1993). The Roman Baths at Bath. Bath: Bath Archaeological Trust.

Grosvenor Museum Chester (2006) Within These Walls: Treasures of Chester at the Grosvenor Museum. Norwich: Jarrold Publishing.

Johnston, D.E. (2002). Discovering Roman Britain ( $3^{\text {rd }}$ ed.). Princes Risborough: Shire Publications.

Ordnance Survey (2016) Roman Britain Historical Map and Guide. Southampton: Ordnance Survey.

Rudkin, D (2008) Fishbourne Roman Palace: An Illustrated Family Guide. Lewes: Sussex Archaeological Society.

Scullard HH (1979) Roman Britain: Outpost of the Empire. London: Thames \& Hudson.

Wilson RJA (2002) A Guide to the Roman Remains in Britain (4th ed.). London: Constable.

\section{Sites and websites}

Angmering Roman Villa (www.angmeringvillage.co.uk/history/villa.htm)

Bath - The Roman Baths (www.romanbaths.co.uk)

Bignor Roman Villa (www.bignorromanvilla.co.uk)

Butser Ancient Farm (www.butserancientfarm.co.uk)

Chester - Amphitheatre (www.english-heritage.org.uk/visit/places/chesterroman-amphitheatre)

Chester - Dewa Roman Experience (www.dewaromanexperience.co.uk)

Chester - The Grosvenor Museum (http://grosvenormuseum.westcheshiremuseums.co.uk)

Cirencester Amphitheatre (www.english-heritage.org.uk/visit/places/ cirencester-amphitheatre)

Chichester - The Novium Museum (www.thenovium.org)

Fishbourne Roman Palace (http://sussexpast.co.uk/properties-to-discover/ fishbourne-roman-palace)

Littlehampton Museum (www.littlehamptonmuseum.co.uk)

Lunt Roman Fort (www.luntromanfort.org)

Wroxeter Roman City (www.english-heritage.org.uk/visit/places/wroxeterroman-city) 